$\square$ LIBROS

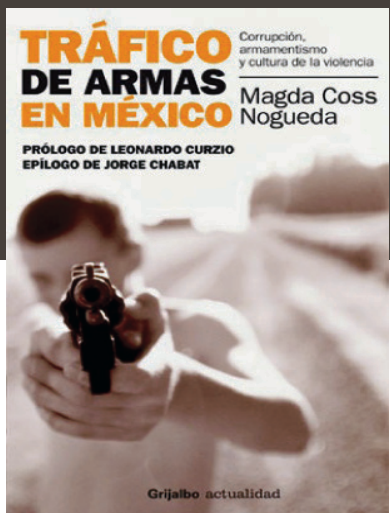

Magda Coss Nogueda, "Tráfico de armas en México. Corrupción, armamentismo y cultura de violencia", Grijalbo, 2011, 199 páginas

\title{
Tráfico de armas en México. Corrupción, armamentismo y cultura de violencia
}

El tráfico de armas es un delito que está acabando con la sociedad. La periodista y escritora Magda Coss Nogueda escribe sobre esta amenaza que está sacudiendo brutalmente las costumbres y las formas de vida de los mexicanos y del mundo.

En México cada día mueren 38 personas a causa de la violencia y al menos las tres cuartas partes de éstas, son a causa de la creciente disponibilidad de armas en dicho país. Por ciento cincuenta dólares, se puede conseguir un arma o rentar una subametralladora automática a los Zetas, e incluso se puede contratar a un ciudadano estadounidense para que compre una 45 nueva en una feria de armas en Estados Unidos. Con ese precio, hasta se puede contratar a un sicario con el muerto incluido, expone la autora. A nivel global, más de 740,000 personas fallecen como consecuencia de la violencia armada, de las cuales 490,000, mueren en zonas donde no hay guerras ni conflictos políticos violentos. Se calcula que anualmente 300,000 personas mueren por lesiones intencionales o accidentales, por el uso de armas de fuego en América Latina, y además, es la cuarta causa de muerte en esa región y es donde ocurre el $48 \%$ de homicidios violentos y el $47 \%$ de los suicidios violentos con armas de fuego en el mundo.

En la sociedad mexicana cualquier persona puede tener un arma, y su portación tiene significados diversos, desde ser un artículo de lujo, o ser un símbolo de masculinidad y tradición, hasta representar una garantía de sobrevivencia; para otros puede ser un artículo que optan por tener en casa para su defensa, sin pensar en los riegos que esto implica. Sostiene la autora que el poseer una pistola o rifle en casa triplica la posibilidad de ser víctima de homicidio, y que la posibilidad de morir aumenta en 12 veces ante una agresión con arma de fuego que con cualquier otra arma, lo anterior se agrava al considerar que es 43 veces más probable que el dueño del arma mate a un familiar o conocido que a un extraño y que el hecho de tener un arma en un hogar con adolescentes, aumenta en 16 veces la posibilidad que éstos cometan suicidio, situación preocupante al considerar que la tasa de mortalidad aumenta después de dicha etapa y que la mayoría de accidentes fatales, homicidios y suicidios se presentan en la población de entre 15 y 29 años. De ahí que el uso de armas pueda ser letal.

Apunta la autora que cada año, ingresan al territorio mexicano por lo menos 300,000 nuevas armas y se estima que ingresan diariamente alrededor de 2,000, principalmente provenientes de Estados Unidos, a través de "compradores de 


\section{LIBROS}

paja", que es el nombre que se le da a las personas que prestan su nombre para comprar alcohol, tabaco, armas y explosivos, siendo las principales ciudades donde se introducen armas de fuego, Tijuana, Mexicali, San Luis, Río Colorado, Ciudad Juárez, Piedras Negras, Nuevo Laredo, Reynosa y Matamoros. Dichas armas son distribuidas en gran cantidad para cárteles del narcotráfico y del crimen organizado, ya que entre un $50 \%$ y un $60 \%$ de los integrantes de éstas, portan armas.

Otra gran cantidad de armas está en poder de ciudadanos comunes, que las portan como símbolo de masculinidad, como lo enmarca la autora al referirse a un joven de nombre Martín de 23 años, quien afirma que "te conviertes en otra persona con arma en el cinto. Tus amigos te ven y te ganas respeto", de ahí que las armas desempeñen un papel en la vida de los hombres, desde niños juegan con espadas, pistolas u otros como armas, a fin de eliminar a su oponente, tomando diversos roles como policías, soldados o narcotraficantes; roles negativos, que no solo enseñan que a través de la violencia pueden obtener ganancias, sino que reafirman la errónea idea de superioridad que históricamente ha tenido el hombre sobre la mujer.

Sostiene la autora que la debilidad de las instituciones mexicanas ha facilitado el comercio ilegal de armas de fuego, por lo que existe la necesidad de replantearse estrategias para el efectivo combate del narcotráfico y del crimen organizado, así como del adecuado resguardo de las fronteras del territorio mexicano. Aunado a ello, debe propiciarse el conocimiento sobre los riesgos a que una persona se expone al adquirir un arma, así como la normativa legal a la que deben someterse. Es primordial promover una masculinidad libre de violencia, que comprenda que a través de las armas no se resuelven los conflictos, y que tampoco son herramientas para mantener la paz, lo que vuelve esenciales fomentar una cultura de tolerancia social.

En la actualidad lo planteado por Magda Coss Nogueda, es la realidad de México, El Salvador y otras naciones que sucumben ante la necesidad de controlar la violencia y terminan aceptando tácitamente que la seguridad pública esta puesta en manos de civiles, que sin saberlo adquieren armas de fuego y se vuelven víctimas de las mismas; en suma de ello, el poco control que se ejerce en las fronteras de nuestros países y la falta de herramientas legales necesarias para el control de este flagelo posibilita el tráfico de armas; mismas que están en poder del crimen organizado y en manos de civiles, que ya sea por masculinidad, lujo, costumbre, o por ser un instrumento de supervivencia, las adquieren indiscriminadamente. Por ello es fundamental educar para la paz desde las primeras edades y garantizar respuestas legales contundentes y eficaces para repeler este mal que tantas vidas cobra día a día.

Sinopsis a cargo de Karlen Judith Moreno González Jefa de la Unidad de Acceso a la Información Pública Dirección General de Centros Penales 